\title{
SILAHLI ÇATIŞMA ESNASINDA KÜLTÜREL MALLARIN \\ ULUSLARARASI TOPLUM YARARINA KORUNMASI
}

\section{PROTECTION OF CULTURAL PROPERTY FOR THE SAKE OF THE INTERNATIONAL COMMUNITY DURING THE ARMED CONFLICT}

DOI: $10.21492 /$ inuhfd.373697

\section{Merve ERDEM*}

\begin{abstract}
Özet
Kültürel malvarlığının korunması, sadece malvarlığının bulunduğu devleti değil, uluslararası toplumu da ilgilendirmektedir. Kültürel mirasa gelen her zarar, insanoğlunun ortak zararı ve kaybıdır. İșbu nedenle, kültürel malvarlığını korumak, uluslararası hukukun, özellikle insancıl hukukun konularından birini oluşturmuştur.

Kültürel malvarlığını korumak için akdedilen antlaşmalar ve ek protokollerle, silahlı çatışmalarda çatışan taraflara, kural olarak, çatışma alanında yer alan kültürel malvarlığını tahrip etmeme ya da yok etmeme yükümlülügü öngörülmüştür. İlgili yükümlülüğün ihlali, ciddi insancıl hukuk ihlaline verecek ve devletler kendi iç hukuk düzenlerinde, sorumluları yargılayabileceklerdir. Ayrıca Uluslararası Ceza Mahkemesi de savaş suçları kapsamında kültürel malvarlığını koruma yükümlügünün ihlallerini yargılamakla yetkilendirilmiştir.

Her ne kadar kültürel malvarlığı, uluslararası hukuk sisteminde, koruma altına alınsa ve yükümlülügün ihlali için bireysel cezai sorumluluk öngörülse de kültürel malvarlığının tahribi ve yok olması geri dönülemez zararlara yol açmaktadır. İşbu nedenle, kültürel malvarlığının pasif koruması yanında, zarar görmeden ya da yok olmadan korunmasını temin altına alacak, aktif koruma araçlarının varlığı daha da önem arz etmektedir.

Anahtar Kelimeler: Kültürel malvarlığının korunması, 1954 Bir Çatışma Halinde Kültür Mallarının Korunmasına Dair Sözleşme, 1977 Ek Protokol I, 1977 Ek Protokol II, Uluslararası Ceza Mahkemesi, Savaş Suçları.

\section{Abstract}

The protection of cultural property concerns not only the state where it is situated but also the international community as a whole. Any harm to cultural heritage also represents a loss for human culture and international society. Therefore, the protection of cultural property has become a subject of international law and humanitarian law in particular.
\end{abstract}

\footnotetext{
* Arş. Grv. Ankara Üniversitesi, Hukuk Fakültesi, Milletlerarası Hukuku Anabilim Dalı, E-mail: merverdem1987@hotmail.com

Makale Gönderilme Tarihi: 02.01.2018

Makale Kabul Tarihi: 17.05.2018
} 
Treaties and additional protocols enacted for the protection of cultural heritage, in principle, provide an obligation to conflicting parties to not destroy or destruct cultural property in conflict zones. Any breach of this obligation constitutes a serious violation of humanitarian law, and it is the states who are competent to adjudicate on the responsible actor in their domestic legal systems. Further, the International Criminal Court is given jurisdiction over breaches of the obligation to protect cultural heritage within the context of war crimes.

Although the international legal system provides protection for cultural property and individual criminal responsability in cases of the breach of this protection, the destruction of cultural property causes irreversible damages. For this reason, in addition to passive protection of cultural property, active protection tools have to be provided in order to protect cultural property before any damage or destruction occur.

Keywords: The protection of cultural property, 1954 Convention for the Protection of Cultural Property in the Event of Armed Conflict, 1977 Additional Protocol I, 1977 Additional Protocol II, The International Criminal Court, War Crimes.

\section{GíRİş}

Uluslararası hukuk kurallarının ihlali, onların varlık sorununa değil etkililik sorununa işaret etmektedir. İşbu etkililik sorunu bakımından en çok karşılaş̧ı̆̆ımız meseleler de jus ad bellum ve jus in bello kuralların uygulanmasına ilişkindir. Hem kuvvet kullanma yasağı, hem de silahlı çatışmalar esnasında insancil hukuk en çok ihlal edilen hukuki rejimlerdendir. Bir silahlı çatışmada, insancıl hukukun gerektirdiği sınırlar her zaman aşılmakta, yükümlülükler daima taraflarca göz ard1 edilmektedir. Söz konusu ihlaller, sivilleri ve en nihayetinde de uluslararası toplumu olumsuz etkileyen boyutlara ulaşmaktadır. Uluslararası toplumu olumsuz etkileyen işbu ihlallerin bir boyutu da önemli kültürel malların, silahlı çatışmalarda yıkıma ve tahribe maruz kalması veya tamamen yok olmasidır.

İlgili yıkım ve tahrip, özellikle 20. yüzyılda insanlığın s1k s1k karşılaştı̆g 1 bir olay haline gelmiş, kültürel mallar, alınan önlemlere rağmen 21. yüzyılda da çatışmaların temel hedefi haline gelmekten kurtulamamıştır. Halbuki, kültürel malvarlığı sadece bir ulusun kültürel mirası değil, tüm insanlığın mirasıdır ${ }^{1}$. Dolayısıyla, kültürel malvarlığına verilen zarar sadece, kültürel malvarlığının bulunduğu ülke halkını değil, uluslararası toplumun bütününü ilgilendirmektedir.

Nitekim en son insanoğlu, yoğunlukla Irak ve Suriye'de faaliyet gösteren Irak-Şam İslam Devleti olarak kendini ilan eden terör örgütünün 2015 yılı Şubat ayının sonlarında Musul Halk Kütüphanesi'ni ateşe

\footnotetext{
${ }^{1}$ O'KEEFE, Roger: The Protection of Cultural Property in Armed Conflict (The Protection of Cultural Property), Cambridge University Press, UK 2006, s. 104.
} 
vermesi ve Musul Müzesi'ne saldırarak, Müze'de bulunan heykel ve diğer sanat eserlerini tahrip etmesine seyirci olmuştur' ${ }^{2}$. Yine benzer bir tahribat aynı yılın Ağustos ayında Palmira antik kentinde yaşanmıştır ${ }^{3}$.

2015 y1lından günümüze yaşanan olaylar, kültürel malvarlığının korunmasını yeniden gündeme getirmiştir ${ }^{4}$. İşbu çalışma, yaşanan bu olaylardan yola çıkarak uluslararası hukuk açısından kültürel malvarlığının uluslararası ve uluslararası silahlı çatışmalarda korunması yükümlülüğ̈nü, yükümlülügün ihlali halinde uygulanabilecek yaptırımları incelemeyi ve nihayetinde rejimin etkililiğini değerlendirmek amacıyla kaleme alınmıştır.

\section{ULUSLARARASI HUKUK AÇISINDAN KÜLTÜREL MALVARLIĞININ KORUNMASI \\ A. Kültürel Malvarlığının Korunması'nda UNESCO Sözleşmeleri’nin ve Uluslararası İnsancıl Hukukun Rolü}

Kültürel malvarlığının korunması hem savaş/silahlı çatışma düzeni hem de barış düzeni bakımından, kültürel malvarlığının tahribi, yok edilmesi ve yasadışı ticaretini yasaklamayı içermektedir. İşbu husus cılız da olsa ilk olarak 18. yüzılda Vattel tarafından dile getirilmiştir. Vattel, The Law of Nations isimli kitabında, sanat eserlerinin tahrip edilmesi ya da savaş ganimeti olarak zapt edilmesine karşı çıkarak, bazı nesnelerin savaşın sebep olabileceği yıkıcı etkisinden uzak tutulması gerektiğini ifade etmiştir. Ancak özellikle kültürel malvarlığının zapt edilmesine yönelik önerileri, söz konusu dönemde kabul görmemiştir5.

${ }^{2}$ https://www.haberler.com/isid-in-musul-muzesi-ne-saldirisi-7015091-haberi/ (Erişim Tarihi: 10.12.2017).

3 "ISIS destroy Palmyra's Roman amphitheatre after 'beheading 4 and shooting 8 dead in ancient city", http://www.mirror.co.uk/news/world-news/isis-destroy-palmyras-romanamphitheatre-9657148, (Erişim Tarihi: 20.12.2016)

4"Destruction of Cultural Heritage in the Middle East by ISIS", http://www.gecmun.com/uploads/2/3/7/0/237 02810/ gecmun_iii_unesco.pdf, (Erişim Tarihi: 20.12.2017); "Syria, Destruction of Cultural Heritage", https://casebook.icrc.org/case-study/syria-destruction-cultural-heritage (Erişim Tarihi: 20.12.2017)

5 BHAT, P. Ishwara: "Protection of Cultural Property Under International Humanitarian Law: Some Emerging Trends", ISIL Yearbook of International Humanitarian and Refugee Law, No: 4, 2001, s. 49; ÖZEL, Sibel: Uluslararas1 Alanda Kültürel Malvarlığının Korunması (Kültürel Malvarlığının Korunması), Alkım Yayınları, İstanbul, 1998, s. 91; TOMAN, Jiri: The Protection of Cultural Property in the Event of Armed Conflict (The Protection of Cultural Property), UNESCO Publishing, Paris, 1996, s. 5. 
Vattel'den sonraki dönemde zamanla, Rousseau'nun kamu malı özel mal ayrımının da etkisiyle, düşmanın kamu mallarının savaş esnasında yok edilebileceği, ancak askeri amaçlarla kullanılmayan kamu mallarının belli bir korumaya tabi olması anlayışı ortaya çıkmıştır. Özellikle silahlı çatışma esnasında, tapınakların, kiliselerin, okulların, kütüphanelerin, laboratuarların ve koleksiyonların korunmasına özen gösterilmeye başlanmıştır ${ }^{6}$.

19. yüzyıla gelindiğinde ise, savaş esnasında kültürel malvarlığının korunmasına dair başka yeni gelişmeler baş göstermiştir. İşbu gelişmelerden biri de, Amerika Birleşik Devletleri'nde kabul edilen Lieber Code'dur. Söz konusu metinde, savaşı kazanan ordunun taşınır malvarlığına el koyma hakkının bulunduğu, ancak kiliseler, hayır ve eğitim kurumlarındaki eşyalara dokunulamayacağı belirtilmiştir ${ }^{7}$. Aynı şekilde 1874 yılında yapılan Brüksel Konferansı'nda kabul edilen Deklarasyon'da, sanata hasredilmiş malvarlığının zapt veya tahrip edilmesi yasaklanmıştır, ancak söz konusu deklarasyon metni, antlaşma metni olarak onaylanmamıştır ${ }^{8}$.

1874 Brüksel Deklarasyonu'nun ardından bir diğer gelişme I. Lahey Barış Konferansı neticesinde akdedilen 1899 Lahey Sözleşmeleri ile II. Lahey Barış Konferansı neticesinde akdedilen 1907 Lahey Sözleşmeleri olmuştur 9 . 1899 II Nolu Kara Savaşının Yasa ve Teamülüne Dair Sözleşme kültürel malvarlığına ilişkin spesifik düzenleme XXVII. madde ile düzenlenmiştir ${ }^{10}$. Buna göre; "askeri amaçlarla kullanılmayan; dine, sanata, bilime ve vakıf amacına özgülenmis yapıların, tarihi anıtların, askeri amaçlarla kullanılan binaların korunması için tüm önlemlerin alınması" öngörülmüştür. İşbu maddede belirtilen koruma, direkt zarar verme ya da yakın hedeflere yapılan bombardıman sonucu kazara firlayan mermi kapsülü, şarapnel, enkaz ya da askeri mühimmatın yol açtığı hasardan korumayı içermektedir. Ancak koruma altındaki eser

\footnotetext{
${ }^{6}$ TOMAN, The Protection of Cultural Property, s. 5

${ }^{7}$ POUST, Jordan: "Dr. Francis Lieber and Lieber Code" (Lieber Code), Proceedings of the Annual Meeting (American Society of International Law), 95, 2001, ss. 112- 115; TECHERA, Erika: "Protection of Cultural Heritage in Times of Armed Conflict: The International Legal Framework Revisited" (Protection of Cultural Heritage), Macquarie J. Int'1\&Comp. Envtl.L, 4(1), 2007, s. 3.

8 TOMAN, The Protection of Cultural Property, s. 9; ÖZEL, Kültürel Malvarlığının Korunmas1, s. 93.

${ }^{9}$ SCOTT, James Brown (ed.): The Hague Convention and Declarations of 1899 and 1907, https://archive.org/stream/ hagueconventions00inteuoft\#page/n5/mode/2up, (Erişim Tarihi: 10.12.2017), 1915, ss. 1 - 30 .

${ }^{10} 1899$ Lahey Sözleşmesi II.
} 
ve yapıların zarar görmesi her türlü tedbire rağmen engellenemediyse, hukuka aykırı değildir ${ }^{11}$.

Yine aynı şekilde 1907 IX Nolu Savaşta Deniz Kuvvetlerinin Bombardımanına Dair Sözleşme'nin II. maddesi uyarınca, “deniz kuvvetleri kumandanınin askeri bir hedefi bombalamayı hedefledigi sürece, yapılan bombardıman neticesinde koruma altındaki yapı ve eserlerin zarar görmesinin engellenemediği durumlarda, ilgili taraf devletin sorumluluğu olmadı̆ $\breve{l}$ " düzenlenmiştir ${ }^{12}$.

1907 IV. Nolu Kara Savaşları Sözleşmesi’nin Lahey Sözleşmeleri'nin LVI. maddesi ile işgal altındaki devlet bakımından kültürel malvarlığının korunmasına ilişkin özel bir düzenleme öngörülmektedir. Buna göre; "belediye malları, dine, vakıf kurumlarına ve eğitime, sanat ve bilime özgülenmiş enstitülerin devlet malı olsa dahi özel malvarlı̆̆ gibi muamele görmeleri” gerektiği düzenlenmiştir. Bunun yanında LVI. maddede, söz konusu bina ve yapılara verilecek zararın, hukuki kovuşturmanın konusu olacağı öngörülmüştür ${ }^{13}$.

1899 ve 1907 Lahey Sözleşmeleri ile kültürel malların korunmasına ilişkin bir takım koruyucu düzenlemeler öngörülmüş olsa bile, I. Dünya Savaşı'nda, Sözleşme'nin pek çok kez ihlal edildiği ve bazı önemli tarihi ve dini yapılara zarar verildiği görülmüştür. Nitekim Belçika'daki Louvain kütüphanesinin yakılması, Fransa'da Reihms katedralinin bombalanması bunlara örnek olarak gösterilebilir ${ }^{14}$. I. Dünya Savaşı'nda kültürel malvarlığına karşı gerçekleştirilen saldırılardan sonra; 1919 Savaştaki Kural ve Örflerin İhlalinden Sorumluluk için kurulan Alt Komisyon ile Paris Barış Konferansı Sorumluluklar Komisyonu Almanya ve müttefiklerin savaş kural ve örflerini ihlaline ilişkin hususları tespit etmekle yetkilendirilmiştir. Kurulan Alt Komisyon savaş suçlarına ilişkin bir taslak liste oluşturmuş, dini, hayır veya eğitim için tahsis edilmiş binaların, tarihi bina ve eserlerin kasıtlı tahrip ve yıkımı savaş suçu olarak nitelendirilmiştir ${ }^{15}$.

1923 y1lına gelindiğinde ise, hava bombardımanını düzenlemeye ilişkin taslak kurallar hazırlamak maksadıyla toplanan Hukukçular Komisyonu, 1923 Lahey Hava Savaşı Taslak Kuralları başlıklı bir metin

\footnotetext{
11 O'KEEFE, The Protection of Cultural Property, s. 24; TECHERA, Protection of Cultural Heritage, s. 5

121907 Lahey Sözleşmesi I.X

131907 Lahey Söleşmesi IV.

${ }^{14}$ ÖZEL, Kültürel Malvarlığının Korunması, s. 94.

${ }^{15}$ O'KEEFE, The Protection of Cultural Property, ss. 43 - 44.
} 
hazırlamıştır. Söz konusu metnin, kültürel malvarlığının korunmasını özel olarak düzenleyen XXIV. maddesinde; "hava aract tarafindan gerçekleştirilen bombardıman esnasında askeri amaçlarla kullanılmayan, kamuya, sanata, bilime, vakuf işlerine özgülenen binalardan ve tarihi anıtların korunması için gerekli tüm tedbirlerin alınması " öngörülmüştür. Ancak söz konusu yapı ve binaların hava aracı tarafindan ayırt edilebilir olması gerektiği ifade edilmiştir ${ }^{16}$.

Devam eden yıllarda ise, Pan-Amerikan Birliği nezdinde 1935 yılında akdedilen Sanatsal ve Enstitüler ile Tarihi Anttların Korunması Antlaşması, kültürel malvarlığının korunmasına ilişkin kaleme alınan diğer bir metin olmuştur. Kısa adıyla Roerich Paktı olarak da anılan Antlaşma; tarihi anıt, müze ve bilimsel, sanatsal, eğitim ve kültürel enstitülerin hem savaş hem de barış zamanı korunmasını düzenlemektedir. Söz konusu Pakt'ın V. maddesinde; "askeri kullanımın ilgili eser ve yapıların ayrıcalığını ortadan kaldırabileceği, ancak askeri gerekliliğin işbu yapılara zarar vermek bakımından meşruluk sebebi olamayacağ düzenlenmiştir. Kültürel malvarlığına ayırt edici bayrak konulması da, ihtiyari de olsa, öngörülmüştür ${ }^{17}$.

1936 yılında cereyan eden İspanya iç savaşı, kültürel malvarlı̆̆ının korunması meselesini bir kez daha uluslararası toplumun gündemine getirmiştir. İç savaş esnasında kültürel malvarlığının uğradığı tahribat, Uluslararası Müzeler Dairesi (OIM)'ni harekete geçirmiş ve Daire bünyesinde, Savaş Zamanında Tarihi Binalar ve Sanat Eserlerinin Korunması Hakkında Uluslararası Sözleşme metni hazırlanmıştır. Söz konusu Sözleşme, Lahey Sözleşmeleri'nde olduğu gibi dini, sanatsal, bilimsel ya da vakıf amacına tahsis edilmiş binaları kapsamayıp, sadece tarihi yapıları koruma amacı gütmektedir ${ }^{18}$.

Ancak II. Dünya Savaşı'nın başlamasıyla, Savaş Zamanında Tarihi Binalar ve Sanat Eserlerinin Korunması Hakkında Uluslararası Sözleşme'nin onaylanması sekteye uğramış; II. Dünya Savaşı da pek çok önemli yapının tahribata uğraması ya da önemli sanat eserlerine ve tarihi eserlere el konulması olaylarına sahne olmuştur. Örneğin Nazi ordusu savaş esnasında Einsatztab adını verilen bir birim eliyle sistematik olarak

${ }^{16}$ O'KEEFE, The Protection of Cultural Property, s. 46; TOMAN, The Protection of Cultural Property, ss. $15-16$.

${ }^{17}$ TOMAN, The Protection of Cultural Property, ss. 16 - 17; O'KEEFE, The Protection of Cultural Property, s. 52.

${ }^{18}$ TOMAN, The Protection of Cultural Property, ss. 16- 17; O'KEEFE, The Protection of Cultural Property, s. 52. 
Avrupa'daki sanat galerilerini, kilise ve müzeleri yağmalamış, ele geçirdikleri eserleri Almanya'ya götürmüştür ${ }^{19}$. Bunun yanında İtalya'daki Monte Cassino manastırının tahrip edilmesi de savaş esnasında, kültürel malvarlıklarının korunması sisteminin yetersiz kaldığını gösteren başka bir olay olmuştur ${ }^{20}$.

Söz konusu olayların da etkisiyle II. Dünya Savaşı'ndan sonra kurulan Birleşmiş Milletler Eğitim, Bilim ve Kültür Örgütü (UNESCO)'nün bünyesinde Bir Çatışma Halinde Kültür Mallarının Korunmasına Dair Sözleşme ve ihtiyari Protokol hazırlanmış ve ilgili metinler 14 Mayıs 1954 tarihinde kabul edilmiştir ${ }^{21}$.

1954 Lahey Sözleşmesi kültürel malların korunması bakımından genel ve özel olmak üzere ikili koruma sistemi öngörmüş; taraf devletlere idari, askeri, cezai yaptırım ve teknik hususlara ilişkin yükümlülükler getirmiştir ${ }^{22}$.

1954 Lahey Sözleşmesi'nin I. maddesi uyarınca;

"menşe veya sahipleri ne olursa olsun; dini veya laik, mimari veya tarihi anitlarla sanat anitlarl, arkeolojik değerdeki yerler, bütünü itibariyle tarihi ve artistik bir alaka arz eden yapı topluluklarl, sanat eserleri, el yazmalarl, kitap ve başkaca tarihi, artistik veya arkeolojik değer taşıyan eşya, bilim koleksiyonlart, önemli kitap, arşiv reprodüksiyon koleksiyonlar ve emsali gibi milletlerin kültür mameleklerinde büyük önemde yeri olan menkul ve gayrimenkul mallar ve gerçek ve başlıca görevi menkul kültür mallarını koruma veya teşhirden ibaret olan müze, büyük kitaplı, arşiv deposu gibi binalar, söz konusu menkul kültürel malların silahlı çatışma halinde korunması için tahsis edilmişs sı̆̆ınaklar, anıt merkezleri" kültür malları olarak tanımlanmıştır.

1954 Lahey Sözleşmesi'nde tanımlanan kültür mallarının koruma altına alınması ve söz konusu korumaya riayet II. maddeyle düzenlenmiş; devam eden III. ve IV. maddelerinde de koruma altına alma ve riayet tanımlamıştır.

\footnotetext{
${ }^{19}$ Ayrıntılı bilgi için bkz. ÖZEL, Kültürel Malvarlığının Korunması, ss. 95 - 100.

${ }^{20}$ TECHERA, Protection of Cultural Heritage, s. 6.

${ }^{21}$ T.C. Resmi Gazete, 12145, 8 Kasım 1965. Bundan sonra 1954 Lahey Sözleşmesi olarak anılacaktır.

${ }^{22}$ HLADIK, Jan: "The 1954 Hague Convention for the Protection of Cultural Property in the event of Armed Conflict: Some Observations on the Implementation at the National Level" in Protection of Cultural Property in the Event of Armed Conflict, International Committee of the Red Cross, Geneva, 2002, ss. 2 - 3.
} 
Buna göre, "taraf devletler kendi ülkeleri üzerindeki kültür mallarını silahl bir çatışmanın önceden tahmin edilebilecek etkilerine karşı koruma altına almayı ve koruma için uygun görecekleri tedbirleri barış zamanından itibaren hazırlamayı taahhüt ederler."

IV. maddede ise, "

"Sözleşme'ye taraf devletler, gerek kendi ülkelerinde gerek diğer yüksek akit tarafların ülkelerinde bulunan kültür mallarlyla bunlarm koruduğu yapıları ve civarlarındaki yerleri, silahlı bir çatışma halinde bu eserleri tahribe veya bozulmaya maruz bırakabilecek maksatlar için kullanmaktan sakınmak ve bu mallara karşı her türlü düşmanca davranıştan kaçınmak suretiyle işbu mallara riayeti taahhüt ederler."

Bunun yanında; "taraf devletler kültür mallarının her ne yoldan olursa olsun çalınması, yağma edilmesini veya kaçırılmasını, bunlara karşı girişilecek her türlü tahrip fiilini yasajlamayı ve önlemeyi, icabında bu tür faaliyetleri durdurmayı da ayrıca taahhüt ederler. Başka bir taraf devletin ülkesi üzerinde bulunan menkul kültür mallarina el koymaktan sakınırlar." Aynı şekilde kültür mallarına karşı misilleme hareketine girişmek yasaklanmıştır.

Aynı şekilde, genel koruma tedbirlerini düzenleyen bölüm içinde işgal halinde kültürel malvarlığının korunması hususu düzenlenmiştir. İlgili V. madde uyarınca;

"bir taraf devletin ülkesini kısmen veya tamamen işgal eden diğer bir taraf devlet/devletler, işgal altındaki ülkenin yetkili millî makamlarınca kendi kültür mallarının koruma altına alınması ve muhafazası yolunda gösterilecek gayretleri imkân nispetinde destekleyeceklerdir."

1954 Lahey Sözleşmesi aynı zamanda barış zamanı alınması gereken tedbirleri düzenlemektedir. Buna göre;

"taraf devletler, barış zamanlarından itibaren askerî kıtalarına ait nizamname ve talimatnamelere, işbu Sözleşmeye riayet edilmesini sağlayacak hükümler vazetmeyi ve keza barış zamanından itibaren silâhlı kuvvetleri mensuplarında, bütün, milletlerin kültürüne ve kültür mallarına karşı bir saygı zihniyeti uyandırmayı taahhüt ederler. Taraf devletler barış zamanından itibaren silâhlı kuvvetleri bünyesinde, görevi kültür mallarına karşı saygll davranılmasina nezaret etmek ve bu malların muhafazası ile vazifeli mülkî makamlarla işbirliği etmek olan servisler 
veya mütehassls memurlar yetiştirmeyi veya ihdas etmeyi taahhüt ederler. ${ }^{, 23}$

Sözleşme'nin XVIII. ve XIX. maddesi, Sözleşme'nin uygulanabileceği çatışmaları tanımlamaktadır. Sözleşme'nin tatbiki başlıklı XVIII. madde uyarınca;

"barış zamanından itibaren yürürlüğe girecek olan hükümler dışında işbu Sözleşme, ilân edilmiş bir harp veya Yüksek Akit Taraflardan ikisi veya daha fazlası arasında zuhur edecek silâhlı bir çatı̧ma halinde, harp hali bunlardan biri veya birkaçı tarafindan kabul edilmemis dahi olsa tatbik edilecektir. Sözleşme keza Yüksek Akit Taraflardan birine ait ülkenin kismen veya tamamen işgalini tazammun eden bütün hallerde, bu işgal hiçbir askerî mukavemetle karşılanmamış dahi olsa tatbik edilecektir. Ayn zamanda, taraflardan biri Sözleşme'nin tarafi olmasa bile, Sözleşme'nin tarafi olan devletler yine işbu Sözleşme ile bağh olmaya devam edecektir. Taraf olmayan devlet de şayet Sözleşme'nin hükümlerini kabul ettiğini beyan eder ve hükümlere uygun davranırsa, Sözleşme hükümleri ile bağll kalacak demektir."

XIX. maddede ise; uluslararası nitelikte olmayan çatışma halleri bakımından Sözleşme'nin uygulanırlı̆̆ı düzenlenmiştir. Buna göre;

"uluslararası nitelikte olmaylp taraf devletlerden birinin ülkesinde silâhlı bir çatışma halinde, hasım taraflardan her biri, bu Sözleşmenin hiç değilse kültür mallarına karşı saygll bulunmasıyla ilgili hükümlerine riayetle mükellef olacaklardır. Çatışmada hasım taraflar, özel anlaşma yoluyla işbu Sözleşme'nin diğer hükümlerinden bir kismını veya tamamını yürürlüğe koymağa gayret edeceklerdir."

Maddenin devamında öngörülen ve uluslararası nitelikte olmayan çatışmalar bakımından önem arz eden bir diğer husus, işbu Sözleşme'nin ilgili çatışmaya uygulanmasının, çatışan tarafların hukuki durumu üzerinde hiçbir etki yaratmayacak olmasıdır.

1954 Lahey Sözleşmesi'nin ikinci bölümünde de özel koruma tedbirlerine ilişkin rejim öngörülmüştür. Öncelikle, Sözleşme hangi kültürel malvarlığı eser ve yapıların özel koruma altına alınabileceğini düzenlemiştir. Buna göre; "silahlı bir çatışma halinde menkul kültür mallarının muhafazasına mahsus sayısı mahdut bir kisım siğınak, anıt merkezleri ve büyük önem taşıyan başlıca gayrimenkul mallar özel koruma altına alınabilirler."

\footnotetext{
${ }^{23} 1954$ Lahey Sözleşmesi, VII. madde.
} 
Sözleşme, bazı kültürel malların özel koruma rejimine tabi olabilmesi için belli şartlar öngörmüştür. Buna göre;

"söz konusu kültürel mallar büyük bir endüstri merkezinden ve bir hava alanı, bir radyo istasyonu, millî müdafaa hizmetinde çalı̧̧an bir müessese, önemli bir liman veya bir demiryolu istasyonu yahut büyük bir ulaştırma yolu gibi hassas bir nokta teşkil eden herhangi mühim bir askerî hedeften gereği kadar uzak bir mesafede bulunmalı ve askerî maksatlarla kullanılmamalıdır."

Kültür malları, "özel koruma altında bulunan kültür malları milletlerarası sicili”ne kaydedilmekle özel koruma altına alınırlar. Bu kaydın icrası ancak işbu Sözleşme hükümleri dairesinde ve bu Sözleşmenin tatbikatıyla ilgili Tüzükte bildirilen şartlar altında mümkün olabilir ${ }^{24}$.

Özel korumanın kapsamına giren bir diğer husus da söz konusu malların naklinin mümkün olmasıdır.

Sözleşme uyarınca; "taraf devletler, uluslararası sicile kaydedilmelerinden itibaren özel koruma altına alınan kültür mallarına karşı her türlü tecavüz hareketinden sakınmak ve civarlarını herhangi askerî maksatlarda kullanilmaktan kaçınmak suretiyle bunların dokunulmazlı̆̆ın teminini taahhüt ederler. ${ }^{25}$

Kültürel malların nakline ilişkin XII. madde uyarınca ise;

"kültür mallarının gerek ülke içinde gerekse başka ülkeye nakli, ilgili taraf devletin isteği üzerine, Tüzükte açıklanan şartlar içinde özel koruma altında yapılır. Özel koruma altındaki nakil, XVI. maddede açıklanan belirtici işareti taşır ve tatbikat tüzügünde bildirilen milletlerarası murakabe altında yapılır. Taraf devletler özel koruma altında yapılan nakliyata karşı herhangi düşmanca bir harekete girişmekten kaçınırlar."

1954 Lahey Sözleşmesi hem genel koruma tedbirleri hem de özel koruma tedbirleri bakımından, kültürel malların işaretlenmesini öngörmüştür. Genel koruma rejimi uyarınca malların işaretlenmesi ihtiyaridir ve ilgili taraf devletin takdirine bırakılmıştır. Özel koruma altına alınan mallar bakımından ise, söz konusu işaretleme bir zorunluluk arz etmektedir ${ }^{26}$. Gerek genel koruma gerek özel koruma tedbirlerine tabi kültürel mallar ise, XVI. maddede belirtildiği üzere, Sözleşme'nin belirtici

\footnotetext{
${ }^{24} 1954$ Lahey Sözleşmesi, VIII. madde.

${ }^{25} 1954$ Lahey Sözleşmesi, IX. madde.

${ }^{26} 1954$ Lahey Sözleşmesi, X. madde.
} 
işareti, uç tarafı sivri, çaprazlama çivit mavisi - beyaz bir arma ile işaretlenecektir ${ }^{27}$. Bu işaret tek olarak veya XVII. maddede bildirilen şartlar altında, bir üçgen teşkil edecek şekilde üç kere tekrarlanmış olarak kullanilacaktır.

1954 Lahey Sözleşmesi, metinde öngörülen yasakların ihlali halinde, sorumlu kişilerin maruz kalacağı yaptırımı taraf devletlere bırakmıştır. Cezalar başlıklı XXVIII. madde uyarınca;

"taraf devletler işbu Sözleşmeyi ihlâl eden veya bu yolda bir emir veren kimsenin, hangi milletten olursa olsun, araştırilarak ceza hukuk ve disiplin cezalarına çaptırlmaları için kendi ceza hukuku sistemleri çerçevesi içinde gereken bütün tedbirleri almayı taahhüt ederler."

1954 Lahey Sözleşmesi ile aynı tarihte imzalanan I. Protokol, Sözleşme ile tanımlanan kültürel malların, işgal edilmiş ülkeden taşınmasına ve başka bir taraf devlete yediemin olarak bırakılmasına ilişkin hükümler öngörmektedir. Protokol, kültürel malların yasadış1 ihracını yasaklamakla birlikte, yediemin olarak başka bir taraf devlete verilmesine cevaz vermektedir.

1954 Lahey Sözleşmesi'nin akdedilmesinden sonra, insancil hukukta meydana gelen gelişmeler neticesinde, 1949 Cenevre Sözleşmeleri'ne ek iki protokol kaleme alınmıştır. Söz konusu protokoller hem uluslararası nitelikte hem de uluslararası nitelikte olmayan silahlı çatışmalara uygulanacak düzeni öngörmekle birlikte, kültürel malvarlığının korunmasına ilişkin de koruyucu hükümler içermektedir. Söz konusu protokollerde, 1899 ve 1909 Lahey Sözleşmeleri’nde olduğu gibi özel mülkiyetin dokunulmazlığı, ayrıca kültürel malvarlığının korunması özel olarak ele alınmıştır. Söz konusu protokoller, mevcut Sözleşme’yi değiştirmekten ziyade, 1954 Sözleşmesi'nin öngördüğü yükümlülükleri teyit etme amacındadır ${ }^{28}$.

Uluslararası silahlı çatışmaları düzenleyen 1977 Ek Protokol I'in LII. maddesi uyarınca, askeri hedef olmayan tüm mallar, sivil nitelikte mallar sayılır ve Protokol'ün koruması altındadır ${ }^{29}$. Dolayısıyla

\footnotetext{
${ }^{27}$ Köşebentlerinde biri, armanın uç tarafına tatbik edilmiş çivit mavisi bir kare ile bunun üst tarafına resmedilmiş yine çivit mavisi bir üçgenden mürekkep bir arma kare ile üçgen her iki yanda birer beyaz üçgen meydana getirirler.

28 Practical Advice for Protection of Cultural Property by ICRC, 2002, https://www.icrc.org/en/document/ practical-advice-protection-cultural-property-eventarmed-conflict-guidelines, (Erişim Tarihi: 15.12. 2017), s. 6.

29 Türkçe Metin için bkz. BATUR YAMANER, Melike/ÖKTEM, Emre, KURTDARCAN, Bleda R./UZUN, Mehmet C.: 12 Ağustos 1949 Tarihli Cenevre
} 
Protokol'ün öngördüğü bu düzenlemeyle dahi, kültürel malvarlığ 1 minimum koruma altına alınmış durumdadır. Kültürel malların korunmasının tek istisnası doğaları, konumları, amaçları ya da kullanımları gereği askeri eylemlere katkıda bulunan ve kısmen ya da tamamen yok edilmesi, ele geçirilmesi ya da etkisiz hale getirilmesi muhakkak askeri avantaj sağlayan objeler bakımındandır. LIII. maddede ise, kültürel malların ve ibadet yerlerinin korunması başlı̆̆ı altında özel hükümler getirilmiştir. İlgili maddede;

"1954 Silahlı Çatı̧̧ma Halinde Kültürel Malların Korunması Hakkında Sözleşme ve diğer uluslararası kaynaklarının hükümlerine halel gelmemek üzere, insanların kültürel ve ruhani miraslarını oluşturan tarihi anttlar, sanat eserleri ya da ibadet yerlerine karşl yöneltilen muhasamat eylemleri, söz konusu malların askeri faaliyetler için kullanılması ve bu tür malların misilleme hedefi haline gelmesi yasaklanmıstır."

Sözleşme'nin IV. bölümünde özel koruma altına alınmış mevki ve alanlar düzenlenmiştir. LIX. Maddede savunulmayan mevki, LX. maddede askerden arındırılmış bölge tanımlanmıştır. Söz konusu bölgeler çatışmanın taraflarının saldırısından vareste tutulduğu için, kültürel malvarlığı da dâhil olmak üzere, ilgili bölgeler belli bir koruma rejimi altına alınmış olmaktadır.

Söz konusu Protokol I'in yaptırıma ilişkin hükümleri LXXXV. maddede, işbu protokolün ihlallerinin bastırılması başlığı altında düzenlenmiş; 4. fikranın $\mathrm{d}$ bendinde kültürel malvarlığının korunmasına ilişkin ihlallerin bastırılması özel olarak düzenlenmiştir. Buna göre;

"halkın kültürel ve ruhani mirasını teşkil eden ve yetkili bir uluslararası örgüt çerçevesinde, özel düzenleme ile özel koruma rejimi açıkça tanımlanan tarihi abideler, sanat eserleri veya ibadet yerlerini saldırının hedefi haline getirmek suretiyle aşırı tahribatına yol açmak" işbu protokolün ihlali kabul edilmektedir.

İşbu tahribatın kasten yapılması gerekmektedir. İlgili protokolün ihlalinin tespiti için malların askeri faaliyetlerin desteklenmesi için kullanıldığına dair açık delil olmalı ve hasar görmüş abide, sanat yerleri ve ibadet yerlerinin askeri hedeflere yakın olmaması gerekir.

1977 Ek Protokol II'de uluslararası olmayan silahlı çatışmaların hukuki rejimi düzenlenmiş ve söz konusu çatışmalar bakımından da

Sözleşmeleri ve Ek Protokolleri (Cenevre Sözleşmeleri), Galatasaray Üniversitesi Hukuk Fakültesi Yayınları, No: 42, İstanbul, ss. 179 - 264. 
kültürel malların korunması rejimi getirilmiştir ${ }^{30}$. İlgili XVI. madde uyarınca;

"1954 Lahey Sözleşmesi'nin hükümleri sakl kalmak üzere, halkların kültürel ve manevi miraslarını oluşturan tarihi anttlara, sanat eserlerine ya da ibadet yerlerine karşı herhangi bir düşmanca davranışta bulunmak ve işbu yapıları askeri faaliyetleri desteklemek amacıyla kullanmak yasaklanmıştır."

Görüldügü üzere, XVI. madde de askeri gereklilik gibi bir istisna getirmemiş, ancak misillemeyi yasaklayan bir hükme de yer vermemiştir. Aynı şekilde Protokol II, sivil halkın mallarına ilişkin bir düzenleme de öngörmemektedir. Söz konusu Protokol II'nin de düzenlemelerinin, kültürel malvarlığının uluslararası nitelikte olmayan silahlı çatışmalarda dahi, konumu ve doğası gereği askeri bir amaca hizmet etmediği sürece korunmasının bir uluslararası örf ve adet hukuku kuralı oluştuğunun göstergesi olduğu ifade edilmektedir ${ }^{31}$.

1980'lerle birlikte başlayan İran - Irak Savaşı'nda, İran'da yer alan kültürel mirasın, oldukça zarar görmesi üzerine, 1991'de I. Körfez Savaşı'nda Kuveyt'teki kültürel malların, 1991 yılında Yugoslavya'da başlayan çatışmalarda Dubrovnik'in zarar görmesi gibi olaylar bir kez daha 1954 Lahey Sözleşmesi'nin mercek altına alınmasına sebep olmuştur $^{32}$. Bunun üzerine UNESCO'da yapılan genel konferansta, UNESCO Genel Direktörü'ne, 1954 Lahey Sözleşmesi'nin uygulanmasını sağlamaya yönelik yeni tedbirler üzerine çalışma görevi verilmiştir ${ }^{33}$.

1954 Lahey Sözleşmesi'nin kültürel malvarlığ şekilde 1999 Protokolü'nde de yer almıştır ${ }^{34}$. Protokol'ün V. maddesinde, barış zamanına ilişkin olarak kültürel malların koruma altına alınması öngörülmüştür. Silahlı çatışma zamanına ilişkin olarak, VI. maddede yine kültürel mallara riayet öngörülmüştür. VI. madde, 1954 Lahey Sözleşmesi'nin IV. maddesinde düzenlenen istisna bendine ilişkin yeni

${ }^{30}$ BATUR YAMANER/ÖKTEM/KURTDARCAN/UZUN, Cenevre Sözleşmeleri, ss. 265 $-276$.

${ }^{31}$ HENCKAERTS, Jean-Marie: "New Rules for the Protection of Cultural Property in Armed Conflict: The Significance of the Second Protocol to the 1954 Hague Convention for the Protection of Cultural Property in the Event of Armed Conflict" (New Rules), in Protection of Cultural Property in the Event of Armed Conflict, International Committee of the Red Cross, Geneva, 2002, s. 28.

${ }^{32}$ O'KEEFE, The Protection of Cultural Property, s. 237.

${ }^{33}$ Records of the General Conference, 1991, s. 57, http://unesdoc.unesco.org/images/0009/ 000904/090448E.pdf, (Erişim Tarihi: 10.11.2017)

${ }^{34} 1999$ Lahey Sözleşmesi Ek Protokol. 
düzenlemeler öngörülmüştür. Buna göre; askeri kültürel malvarlığına karşı direkt saldırı, ancak kültürel malvarlığının askeri amaçlarla kullanılması ve çatışmanın diğer tarafına karşı askeri avantaj elde etmek için söz konusu kültürel malvarlığına saldırmak dışında başka bir seçenek olmaması halleri için askeri gereklilik kapsamında meşru kabul edilebilecektir. Böylelikle 1954 Lahey Sözleşmesi'nin IV. maddesi ile getirilen istisna daraltılmıştır.1999 Protokolü'nün VII. maddesinde ise,

"çatışmanın tarafları, askeri operasyon düzenlerken, operasyon hedeflerinin 1954 Lahey Sözleşmesi'nin IV. maddesi ile korunan kültürel mallardan biri olmadığını teyit etmekle yükümlüdür. Aynı zamanda, çatışmanın tarafları kültürel malvarlı̆ğnın kazara zarar görmesini engellemek veya en aza indirmek için gerekli tedbirleri almalıdır."

Yine VIII. maddede de taşınır kültür mallarının korunmasına ilişkin taraflara tedbir alma yükümlülüğü öngörülmüş; IX. maddede ise, işgal altındaki ülke bakımından kültürel malvarlığının korunmasına ilişkin 1954 Lahey Sözleşmesi'ne ek yükümlülükler getirilmiştir.

1954 Lahey Sözleşmesi’nde olduğu gibi; 1999 Protokolü'nde de kapsamlı koruma başlığı altında kültürel malvarlığı bakımından özel bir koruma rejimi öngörülmüştür. Ancak Protokol uyarınca, 1954 Lahey Sözleşmesi'nde olduğu gibi, kültürel malvarlığının kapsamlı koruma altına alınması için belli başlı şartları taşıması gerekmektedir ${ }^{35}$. Buna göre;

"kültürel malvarlığının insanlık için büyük önem arz etmesi, korunması için kültürel ve tarihi değerinin taninarak gerekli teknik ve idari tedbirlerin alınmıs ve en yüksek seviyede korunuyor olması ve askeri amaçlarla kullanılmıyor olması ve kültürel malvarlığının askeri amaçlarla kullanılmadı̆̆ının, ilgili devlet tarafindan beyan edilmesi gerekmektedir."

Söz konusu statünün elde edilebilmesi için, her bir taraf 1999 Protokolü ile kurulan Komite'ye, kapsamlı koruma altına alınmasını istediği kültürel malların listesini ibraz etmelidir ${ }^{36}$.

1999 Protokolü'nde Sözleşme'nin ve Protokol'ün ihlali halinde sorumluluk ve yargı yetkisine ilişkin ayrıntılı düzenlemeler öngörülmüştür. Protokol'ün ciddi ihlallerinin düzenlendiği XV. madde uyarınca;

\footnotetext{
351999 Protokolü X. madde.

${ }^{36} 1999$ Protokolü XI. madde.
} 
"kapsamlı koruma altına alınan kültürel malvarlı̆̆ına kasten saldırı, askeri faaliyetleri desteklemek amactyla kapsaml koruma altındaki kültürel malvarlığının ya da civarının kullanılması, işbu Protokol ve Sözleşme ile korunan kültürel malvarliğının saldırı, çalınma ve yağmaya maruz kalması veya şiddet içeren faaliyetlere maruz kalması" Protokol'ün ciddi şekilde ihlaline vücut vermektedir. Ayrıca Protokol'ün ciddi ihlalini gerçekleştiren kişilerin ulusal ve uluslararası hukuktan doğan bireysel cezai sorumluluğunun bertaraf edilemeyeceği belirtilmiştir.

1999 Protokolü'nün XXII. maddesi, uluslararası nitelikte olmayan çatışmalara ilişkin olarak da Protokol'ün uygulanırlığını düzenlemiştir. Ancak Protokol'ün söz konusu silahlı çatışmalara uygulanması, "taraf devletin egemenlik haklarına, ülke içerisinde yeniden düzen ve nizamın kurulması için gerekli meşru tedbirler almasına, milli birlik ve ülkesel bütünlügü̈nü savunmasına halel getirmeyecektir.” Ayrıca taraf devletin XV. maddede öngörülen ihlaller bakımından öncelikli yarg1 yetkisi mevcuttur. 1999 Protokolü, 1954 Lahey Sözleşmesi ile kurulan kültürel malvarlığının korunması sistemine ek olarak Silahlı Çatışmalar Halinde Kültürel Mirasın Korunması Komitesi ve Silahlı Çatışmalar Halinde Kültürel Malvarlığının Korunması Fonu'nu getirmiştir ${ }^{37}$.

UNESCO Genel Konferans1, 27. oturumda, silahlı çatışmada kültürel malvarlığının korunması için gerekli temel ilkeleri beyan etmiştir. Söz konusu ilkeler hem uluslararası hem de uluslararası nitelikte olmayan silahlı çatışmalar bakımından çatışmanın taraflarının Sözleşme'den doğan yükümlülüklerini ortaya koyan işbu kuralların uluslararası örf ve adet hukuku kuralları haline geldiğinin söylenebileceği ifade edilmiştir ${ }^{38}$.

Buna göre 1899 ve 1907 Lahey Sözleşmeleri’nin özellikle kültürel malvarlığının korunması bakımından, uluslararası örf ve adet hukuku kuralına dönüştüğü ifade edilmektedir ${ }^{39}$. Aynı şekilde, silahlı çatışmalarda kültürel malvarlığının korunmasına ilişkin özel olarak akdedilen ve geniş katılımlı bir sözleşme olan 1954 Lahey Sözleşmesi'nin kültürel malların korunmasına ilişkin temel kurallarının da uluslararası örf ve adet hukuku kurallarına dönüştüğü ifade edilmektedir ${ }^{40}$. Nitekim silahlı çatışmalarda

\footnotetext{
${ }^{37} 1999$ Protokolü XXIV. ve XXIX. madde.

38 Records of the General Conference, (1993), s. 40, http://unesdoc.unesco.org/images/0009/ 000956/095621E.pdf (Erişim Tarihi: 10.11.2017)

${ }^{39}$ Practical Advice for Protection of Cultural Property by ICRC, 2002, s. 5; PARTSCH, Karl Josef: "Protection of Cultural Property", in Fleck, Dieter (ed.), The Handbook of Humanitarian Law in Armed Conflict, Oxford University Press, NewYork 2004, s. 382.

${ }^{40}$ HENCKAERTS, New Rules, s. 27.
} 
kültürel malların kasten tahrip ya da yok edilmesine ilişkin kuralların uluslararası örf ve adet hukuku kuralı haline geldiği Eski Yugoslavya için Uluslararası Ceza Mahkemesi'nin (EYUCM) Dario Kordic ve Mario Cerkez kararında teyit edilmiştir ${ }^{41}$.

Sonuç olarak uluslararası hukuk bünyesinde silahlı çatışmalar esnasında kültürel malvarlığının korunması yükümlülüğü ayrıntılı olarak düzenlenmiş, getirilen koruma rejimi belli şartlara bağlanmıştır. Sözleşme'nin ve Protokol'ün geniş katılıma sahip olması dolayısıyla, artık kültürel malvarlığının korunmasını öngören temel kuralların, uluslararası örf ve âdet hukuku kuralına dönüştüğü kabul edilmektedir. Bu nedenle de Sözleşme ve Protokollerin ilgili hükümleri silahlı çatışmalarda yer alan tarafların tümünü bağlamaktadır.

\section{B. Kültürel Malvarlığının Korunmasında Uluslararası Ceza Hukukunun Rolü}

\section{Genel Olarak}

Klasik uluslararası hukuk bakımından uluslararası hukukun süjeleri, devlet ve uluslararası örgütler olarak ifade edilmekte; işbu tüzel kişiliklerin uluslararası hukuk düzeni içinde hak ve yükümlülükleri olduğu görülmektedir. Ancak uluslararası hukuk düzeninin geçirdiği/geçirmekte olduğu dönüşüm/yenilikler dolayısıyla, hukuk düzeninin hak ve yükümlülükler verdiği yeni aktörler de karşımıza çıkmaktadır. Uluslararası hukuk düzeni artık gerçek kişileri de korumaya ilişkin kural ve sistemler içermektedir. Bunun yanında gerçek kişilere verilen haklar yanında, gerçek kişilerin uluslararası hukuk kurallarına riayet etme yükümlülüğü de bulunmaktadır. Bunun nedeni olarak da uluslararası kuralların ihlal edilmesi halinde devletlerin gerçek kişilere yaptırım uygulayamaması ve uluslararası hukuk düzenini ihlal eden bazı suçların cezasız kalması olarak gösterilmektedir ${ }^{42}$.

Uluslararas1 toplumun huzur ve düzenini bozan ve uluslararas1 toplumun maruz kaldığı fiiller uluslararası suç olarak adlandırılmaktadır ${ }^{43}$. Uluslararası suçun işlemesi safhasında, suç işleyen kişinin devletle bir bağlantısının olması veyahut devlet ajanı olması şart değildir. Uluslararası suçlar genelde sınıraşan bir niteliğe sahipse de devletin ülke sinırları

\footnotetext{
${ }^{41}$ Procecutor v. Dario Kordic and Mario Cerkez Judgement, IT-95-14/2-T, 26 February 2001, para. 206.

42 AYDIN, Devrim: "Uluslararası Ceza Hukukunun Gelişimi”, Ankara Üniversitesi Hukuk Fakültesi Dergisi, 52(4), 2002, s. 140

${ }^{43}$ TEZCAN, Durmuş/ ERDEM, Mustafa Ruhan/ÖNOK, Rıfat Murat: Uluslararası Ceza Hukuku (Uluslararası Ceza), Seçkin Yayınları, Ankara 2014, s. 37.
} 
içinde gerçekleşen, uluslararası nitelikte olmayan silahlı çatışmalar esnasında işlenen bazı fiiller de uluslararası suç sayılabilmektedir. Bunun yanında belli bir devlet ülkesi sınırları işlense de, uluslararası suçun niteliği gereği, sorunun salt ulusal olduğunu söylemek mümkün değildir ${ }^{44}$.

Kültürel malvarlığının korunması bakımından uluslararası insancı1 hukukun kapsamlı ve ayrıntılı düzenlemeler getirdiği ve işbu kuralların hem uluslararası silahlı çatışmalar hem de uluslararası nitelikte olmayan silahlı çatışmalara uygulanmasının artık bir uluslararası örf ve adet hukuku kuralı haline geldiği ifade edilebilir.

\section{Kültürel Malvarlığının Korunması ve Savaş Suçları}

Uluslararası insancıl hukukun düzenlediği kültürel malvarlığının korunmasına rejimine ilişkin en zayıf husus, Sözleşmelerin ihlali halinde, sorumluların maruz kalacağ 1 yaptırım rejimidir. 1999 Protokolü dışında, diğer tüm metinler, Sözleşmelerin ihlali halinde ilgililerin maruz kalacağ 1 yaptırımı düzenlemeyi taraf devletlere bırakmıştır. Kültürel malvarlığının korunması konusunda dahi etkili olamayan devletler, çatışma sonrası, sorumluları cezalandırmakla görevlendirilmektedir. Bu durum kanımızca Sözleşme'nin yaptırım sisteminin etkisiz kalmasına, somut olaylarda da görüldüğü üzere, sebep olmaktadır.

Söz konusu etkisizlik, uluslararası cezai sorumluluk kavramı ile bir nebze de olsa giderilmeye çalışılmaktadır. Nitekim uluslararası ve uluslararası olmayan çatışmalarda sivil mallara ya da dini eğitim, sanat, bilim ya da vakıf amacına özgülenen, tarihi yapılar gibi askeri olmayan hedeflere doğrudan yapılan saldırılar savaş suçu kabul edilerek bireylerin cezai sorumluluğuna vücut vermektedir ${ }^{45}$.

Savaş suçları da tıpkı diğer uluslararası suçlar gibi yeni bir kavram değildir. Nuremberg Mahkemesi Şartı'nda (I. madde), EYUCM Statüsü'nde (III. madde) ve Ruanda için Uluslararası Ceza Mahkemesi Statüsü'nde (IV. madde) yer almıştır. Savaş suçlarının aynı zamanda uluslararası örf ve âdet hukuku kuralı oluşturduğu ifade edilmektedir. Örneğin Nuremberg yargılamalarında 1907 Lahey Sözleşmeleri'nin uluslararası örf ve âdet hukuku kurallarını içerdiği, Sözleşmelerin açıkça düzenlenmese dahi ihlallerinin savaş suçuna vücut vereceği belirtilmiştir ${ }^{46}$.

\footnotetext{
${ }^{44}$ TEZCAN/ERDEM/ÖNOK, Uluslararası Ceza, s. 38.

${ }^{45}$ Practical Advice for Protection of Cultural Property by ICRC, 2002, s. 6.

${ }^{46}$ CRYER, Robert/ FRIMAN, Hakan/ROBINSON, Darry/WILMSHURST, Elizabeth: An Introduction to International Criminal Law and Procedure (An Introduction), Cambridge University Press, UK 2014, s. 271.
} 
Savaş suçları kavramı 1949 Cenevre Sözleşmeleri'nde doğrudan kullanılmamış; Sözleşmelerde ciddi ihlal kavramına yer verilmiştir. Nitekim savaş suçları genel olarak insancıl hukuk ihlallerinin ciddi ihlali olarak tanımlanmaktadır, bu bakımından sıradan insancil hukuk ihlallerinden ayrılmaktadır ${ }^{47}$. Daha az ağırlığa sahip ihlaller salt Sözleşmelerin ihlali olup, Sözleşme'lerin söz konusu ihlallerde öngördüğü yaptırıma tabi olacaktır ${ }^{48}$.

Savaş suçunun vücut bulabilmesi için bir uluslararası ya da uluslararası nitelikte olmayan çatışmanın varlığ 1 şarttır ${ }^{49}$. Tarihsel süreç içerisinde savaş suçu kavramı uluslararası silahlı çatışma halleri bakımından ortaya çıkmıştır ve bu nedenle de sadece uluslararası silahlı çatışma halleri bakımından söz konusu olabileceği anlayışı hâkim olmuştur $^{50}$. Ancak EYUCM'nin 2 Ekim 1995 tarihinde verilen Tadic kararı ile savaş suçlarının, uluslararası niteliğe haiz olmayan silahlı çatışmalar bakımından da uygulabileceği kabul edilmiştir. ${ }^{51}$ Nitekim 1995 Tadic kararından sonra uluslararası nitelikte olmayan silahlı çatışmalarda da savaş suçları işlenebileceği Uluslararası Ceza Mahkemesi (UCM) Roma Statüsü ile de kabul edilmiştir ${ }^{52}$.

Uluslararası silahlı çatışmalar bakımından ilgili kuralların uygulanmasinda sorun olmasa da uluslararası nitelikte olmayan silahlı çatışmalarda kültürel malvarlığının korunması yükümlülüğünün ve savaş suçuna ilişkin yaptırımların uygulanmasının bir takım sorunlara yol açabileceği belirtilmektedir ${ }^{53}$. Söz konusu uygulamaya ilişkin en temel sorun uluslararası nitelikte olmayan silahlı çatışmanın tespitidir. Nitekim

${ }^{47}$ SMEULERS, Alette/GRUNFELD, Fred: International Crimes and Other Gross Human Rights Violations a Multi and Interdisciplinary Textbook (International Crimes and Other Gross Human Rights Violations), Martinus Nijhoff Publishers, Leiden 2011, s. 40.

${ }^{48}$ BANTEKAS, Illias/NASH, Susan: International Criminal Court, Routhledge, UK 2007, s. 113.

49 AKSAR, Yusuf: Implementing International Humanitarian Law from the Ad Hoc Tribunals to a Permanent International Criminal Court (Implementing International Humanitarian Law), Routhledge, London 2004, s. 120.

${ }^{50}$ DARCY, Shane: Judges, Law and War: The Judicial Development of International Humanitarian Law (Judges, Law and War), Cambridge University Press, UK 2014, ss. $266-278$.

${ }^{51}$ Prosecutor v. Dusko Tadic (a/k/a Dule), No IT-94-1-AR-72, 2 Ekim 1995, para. 87 - 93.

52 Ayrıca bakınız. SCHABAS, William: An Introduction to the International Criminal Court (An Introduction), Second Edition, Cambridge University Press, UK 2004, ss. 51 65.

${ }^{53}$ ROWE, Peter: "War Crimes", in McGOLDRICK, Dominic/ROWE, Peter/DONNELLY, Eric (ed.), The Permanent International Criminal Court: Legal and Policy Issues, Hart Publishing, USA 2004, s. 230. 
UCM Roma Statüsü'nde yer verilmekle birlikte uluslararas1 nitelikte olmayan silahlı çatışmalar tanımlanmamıştır. Bu noktada uluslararası nitelikte olmayan silahlı çatışmalardan ne anlaşılması gerektiği önem arz etmektedir.

Öncelikle UCM Roma Statüsü'nün uluslararası nitelikte olmayan silahlı çatışmalar bakımından, 1977 Ek Protokol II'deki koşulların aynısını aramadığ1 söylenebilir ${ }^{54}$. Dolayısıyla uluslararası nitelikte olmayan silahlı çatışmalarda UCM'nin devreye girebilmesi için çatışmanın yoğunluğu ve tarafların belli ölçüde örgütlenmiş olması ölçütleri yeterli olacaktır. Bir başka deyişle, uluslararası nitelikte olmayan silahlı çatışmaların Statü bakımından tespiti için, uluslararası insancıl hukuk standartlarının katı uygulanması söz konusu olmayacaktır ${ }^{55}$. Ayrıca Statü'de basit iç gerginlikler, iç karışıklıklar ve münferit ve düzensiz şiddet olayları ile uluslararası nitelikte olmayan silahlı çatışmalar arasında bir ayrıma gidilmektedir. Statü'de düzenlenen savaş suçlarının uygulama alanı genişletilmiş olsa da basit iç gerginlikler ve iç karışıklıklar Statü'nün kapsamından müstesna tutulmuştur. Ancak bir devletin toprakları içinde hükümet kurumları ile organize silahlı gruplar arasında uzun süreli silahlı çatışma meydana gelirse uygulanır ${ }^{56}$.

Aynı zamanda UCM Roma Statüsü, EYUCM içtihadına da paralel bir biçimde hiçbiri hükümetle bağlantılı olmayan, iki veya daha fazla muhalif organize grup arasındaki çatışmalarda da savaş suçu işlenebileceğini öngörmektedir. Organize olma dışında, sadece çatışmanın süresine ilişkin bir kıstas getirilmiş, işbu kıstas da organize silahlı grubun uzunca bir süre boyunca askeri operasyon planlama ve icra etme kabiliyetine sahip olması şeklinde ele alınmıştır ${ }^{57}$.

Toparlamak gerekirse EYUCM İstinaf Dairesinin Tadic kararına tespit edilen ve UCM Roma Statüsü'nde de benimsendiği üzere savaş suçundan bahsedebilmek için şu dört koşul aranmalıdır: İhlal, uluslararası insancıl hukukun herhangi bir kuralına aykırılık teşkil etmelidir; söz konusu kural uygulanabilir bir antlaşma hükmünde ya da uluslararası örf ve âdet hukukunda yer almalıdır; ihlal ciddi olmalıdı, yani söz konusu kural önemli değerleri korumalı ve mağdur bakımından ağır sonuçlar

\footnotetext{
${ }^{54}$ DARCY, Judges, Law and War, s. 109.

${ }_{55}^{5}$ AKSAR, Implementing International Humanitarian Law, s. 123.

${ }^{56}$ UCM Roma Statüsü, 8/II-f bendi.

${ }^{57}$ Tadic Judgement, para. 70; Bkz. TEZCAN/ERDEM/ÖNOK, Uluslararası Ceza, s. 478; BIANCHI, Andrea- NAQVI, Yasmin: International Humanitarian Law and Terrorism, Hart Publishing, USA 2011, s. 114.
} 
doğurmalıdır; ihlal hem uluslararası antlaşmalar hukuku hem de örf ve âdet hukuku kuralları bakımından bireysel cezai sorumluluğun doğmasını gerektirmelidir $^{58}$.

Savaş suçları ile insanlığa karşı suçlar arasındaki fark bakımından, savaş suçlarının en önemli unsuru silahlı çatışmalar esnasında ciddi insancıl hukuk ihlallerinin vücut bulmasıdır. Dolayısıyla bir ihlalin savaş suçuna vücut verebilmesi için ihlale sebep olan fiilin silahlı çatışma ile ilgili olması gerekmektedir. İnsanlığa karşı suçlar da aslında savaş suçları ile alakalı olsa da insancıl hukukun belli bir ağırlığa varmayan ihlallerini kapsam içine almaktadır. Burada en önemli unsur, fiilin sivil nüfusa karş1 yaygın ve sistematik bir saldırı biçiminde cereyan etmesidir. İnsanlığa karşı suçun, savaş suçundan ayrılan bir diğer unsuru da ihlale yol açan fiillerin silahlı çatışma ile bağlantısı olmasının şart olmamasıdır ${ }^{59}$.

Savaş suçunun manevi unsuru kasttır. İşbu suçun oluşması için genel kast yanında, özel kast da aranmaktadır. Söz konusu özel kast silahlı çatışmanın varlığı ve saldırı kastı dışında, savaş kurallarını ihlaldir ${ }^{60}$. Savaş suçlarının düzenlendiği UCM Roma Statüsü'nün 8/II-a.iii bendi uyarınca; "askeri gereklilik olmaksızın keyfi ve yasadışı olarak malların yaygin bir şekilde yok edilmesi veya sahiplenilmesi suretiyle 1949 Cenevre Sözleşmeleri'nin ciddi ihlali”, 8/II-b.ix bendi uyarınca,

"askeri amaçlı olmaması koşuluyla dini, eğitim, sanat veya vakıf amacina özgülenmiş binalara, tarihi eserlere, hastanelere ve hasta ve

\footnotetext{
${ }^{58}$ Tadic Judgement, para. 94. Ayrıca YUCM çeşitli davalarda silahlı muhalif grupların iç organizasyonunun gelişmişlik derecesini gösterebilecek bazı kıstaslar önermektedir. ${ }^{58} \mathrm{Bu}$ kıstaslar kabaca şöyle ifade edilebilir: Bir emir komuta sisteminin varlığı, grup içerisinde disiplin kurallarının ve disiplin mekanizmalarının varlığı, merkezlerin mevcudiyeti, grubun belirli bir bölgeyi kontrol ediyor oluşu, grubun silahlara ve diğer askeri teçhizata ulaşma kabiliyeti, grubun adam toplama ve askeri eğitim verme konularında ne derece başarılı olduğu, grubun birlik olarak hareket ve lojistik içeren askeri operasyonlar planlama, koordine etme ve gerçekleştirme kabiliyeti, grubun belirli askeri stratejiler belirleme ve askeri taktikler kullanma yeteneği, grubun tek ses olabilme, müzakere edebilme, ateşkes veya barış antlaşması imzalama kabiliyeti. Bkz. YUCM, Prosecutor v Haradinaj, Dava No. IT-04-84-84-T, (Dava Dairesi), 3 Nisan 2008, para. 60. Ayrica YUCM, Prosecutor v. Boskoski, Dava No. IT-04-82, (Dava Dairesi), 10 Ağustos 2008, para.199- 203.

59 BAŞAK, Cengiz: Uluslararası Ceza Mahkemesi ve Uluslararası Suçlar (Uluslararası Ceza Mahkemesi), Turhan Kitabevi, Ankara 2003, s. 182; CASSESE, Antonio: International Criminal Law, Oxford University Press, UK 2003, ss. 54 - 56; SMEULERS/GRUNFELD, International Crimes and Other Gross Human Rights Violations, s. 46;

${ }^{60}$ BAŞAK, Uluslararası Ceza Mahkemesi, s. 181; CASSESE, International Criminal Law, ss. $57-58$.
} 


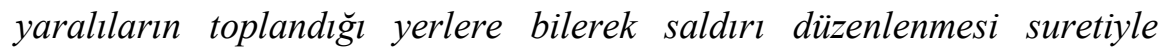
mevcut kurulu uluslararası hukuk çerçevesinde savaş hukukuna uygulanabilir kural ve örf ve adet hukukunun ihlal edilmesi";

8/II-e.iv bendinde; "askeri amaçlı olmaması koşuluyla dini, eğitim, sanat, bilim veya vaklf amacına özgülenmis binalara, tarihi eserlere, hastanelere ve hasta ve yaralıların toplandiklart yerlere bilerek saldır suretiyle mevcut uluslararası hukuk çerçevesinde uluslararası savaş hukukuna uygulanabilir uluslararası nitelikte olmayan çatışmalara uygulanan kural ve örf ve adet hukukuna aykırl faaliyetler" kültürel malvarlığının korunmasına aykırı faaliyetler bakımından savaş suçuna vücut veren ihlaller olarak düzenlenmiştir.

1949 Cenevre Sözleşmeleri'nde de ortak 3. maddenin uygulandığ 1 durumlar bakımından, çatışma dışı kalmış kişilere karşı şiddet, kasten öldürme, sakat bırakma, acımasız muamele ve işkence, insan onuruna hakaret eden ve aşağılayan davranışlar, rehine alınması, yargısal güvenceler olmaksızın yargılama ve infaz, savaş suçları arasında sayılmıştır.

Görüldügü üzere, UCM Roma Statüsü, uluslararası inancıl hukuk kurallarının ihlaline ilişkin bireysel cezai sorumluluğa ilişkin uluslararası örf ve âdet hukuku kurallarını yansıtmakta, yeni bir suç kategorisi yaratmamaktadır ${ }^{61}$. Bunun yanında, kültürel malvarlı̆̆ına karşı saldırının, UCM Roma Statüsü'nün 7/I-h bendinde kaleme alınan insanlığa karşı suç da oluşturduğu ifade edilmektedir. Çünkü kültürel malvarlığına saldırının, sivil halka karşı yaygın ve sistematik saldırı olarak yorumlanabileceği belirtilmektedir ${ }^{62}$.

Kültürel malvarlığının korunması bakımından getirilen istisna ise askeri gereklilik ve kültürel malların askeri amaçlarla kullanılması halidir. Nitekim askeri gereklilik ilkesi, düşmanın teslim olmasını sağlamak amacıyla alınabilecek askeri tedbirler şeklinde tanımlanmaktadır. Bu ilke savaşan tarafin, düşmanın kısmen veya tamamen boyun eğmesini sağlamaya yetecek derecede kuvvet kullanılmasına imkân vermektedir ${ }^{63}$. Askeri gereklilik ilkesi, insancil hukuk ihlallerinin istisnası olarak hem uluslararası örf ve âdet hukuku kurallarında hem de sözleşmelerde yer

\footnotetext{
${ }^{61}$ ROWE, s. 208; SCHEFFER, David: "The International Criminal Court" in SCHABAS, William/BERNAZ, Nadia (ed.), Routhledge Handbook of International Criminal Law, Routhledge, London 2010, s. 72.

${ }^{62}$ O'KEEFE, The Protection of Cultural Property, ss. $351-352$.

${ }^{63}$ GÜNEYSU, Gökhan: “Askeri Gereklilik İlkesi ve Uluslararası İnsancıl Hukuk”, Ankara Barosu Dergisi, 4, 2012, s. 99.
} 
almaktadır. Her ne kadar uluslararası nitelikte olmayan silahlı çatışmalar bakımından askeri gereklilik ilkesinin varlığı tartışılsa da uluslararası hukuk kuralları uluslararası nitelikte olmayan silahlı çatışmalarda da malvarlığının korunması bakımından istisna olarak karşımıza çıkmaktadır ${ }^{64}$.

Kültürel malvarlığının askeri amaçlarla kullanılması halinde ise, kültürel malvarlığı askeri hedef haline gelecektir. Askeri hedef; nitelikleri, yeri, amacı veya kullanımı, askeri harekâta etkin katkı sağlayan ve tamamen veya kısmen tahribi, zaptı veya etkisiz kılınması saldırının yapıldı ̆̆ 1 andaki hal ve şartlar altında kesin yarar sunan mallardır. Askeri hedef olmayan tüm hedeflerse, sivil hedef sayılır. Hedefin niteliğinden kuşku duyuluyorsa, askeri hedef olarak nitelendirilmez. Askeri gereklilik ve askeri amaç kavramları, kültürel malvarlığına saldırıyı meşrulaştırdığ 1 için, kültürel malvarlığına saldırı nedeniyle oluşan savaş suçları bakımından hukuka uygunluk nedeni teşkil edecektir ${ }^{65^{5}}$.

Özetle kültürel mallara yapılan saldırıların savaş suçu sayılabilmesi için öncelikle ortada uluslararası veya uluslararası nitelikte olmayan bir silahlı çatışma olmalıdır. Söz konusu saldırı neticesinde kültürel malvarlığı zarar görmeli, malvarlığı askeri amaçlarla kullanılmamalı ve askeri hedeflere de çok yakın olmamalıdır. Kültürel mallara saldırı kasten yapilmalidir.

Uluslararası ve uluslararası nitelikte olmayan silahlı çatışmalarda gerçekleştirilen faaliyetlerin savaş suçu olarak nitelendirilmesi, meselenin başlangıç aşamasını teşkil etmektedir. Savaş suçlarının işlendiğinin tespit edilmesinden sonra, suçun faillerinin yargılanması gündeme gelecektir. Nitekim savaş suçlarının faillerinin yargılanması tarih boyunca son derece güç bir sorun olmuş ve sorunun bertaraf edilip savaş suçlarının yargılanması için farklı çözümler ileri sürülmüştür. İleri sürülen çözümlerden biri, savaş suçu faillerinin ulusal mahkemelerde yargılanmasıdır $^{66}$. Bu nedenle günümüzde uluslararası hukukun suça ve suçlulara ilişkin temel ilkesi mülkilik ilkesi olmuştur. Söz konusu ilkeye

\footnotetext{
${ }^{64}$ DARCY, Judges, Law and War, 146.

${ }^{65}$ TÜTÜNCÜ, Ayşenur: İnsancıl Hukuka Giriş (İnsancıl Hukuk), Beta Yayınları, İstanbul 2006, s. 82.

Ancak askeri gereklilik ilkesinin ne olduğu ve kim tarafindan tayin edileceği konusunda çeşitli tartışmalar ve farklı yaklaşımlar mevcuttur. Ayrıntılı bilgi için bkz. BHAT, s. 54.

${ }^{66}$ Nitekim ilgili husus 1954 Lahey Sözleşmesi'nde bizzat öngörülmüştür.
} 
göre, suçun işlendiği ülkenin devleti uygulanacak hukuk ve yargılama bakımından öncelikle yetkilidir ${ }^{67}$.

Mülkilik ilkesi haricinde, uluslararası suçlar bakımından evrensel yargı yetkisi kabul eden devletler, kendi ülke sınırları dışında gerçekleşen silahlı çatışmalar esnasında işlenen savaş suçları dolayısıyla yargı yetkisine sahip olabilecektir. Evrensellik ilkesi gereğince, devletlerin savaş suçu sanıklarının bireysel cezai sorumluluğunu ortaya koyması yeterli olamayıp devletlerin savaş suçlusu sanıklarını tutuklama, soruşturma ve yargılama yükümlülügü mevcuttur. Tabi bu yükümlülük savaş suçları ya da genel olarak uluslararası suçlar bakımından evrensellik ilkesini kabul eden devletler nezdinde mevcut olacaktır ${ }^{68}$. Devletler ayrıca, kişi bakımından yargı yetkisi sebebiyle, kendi tabiiyetinde bulunan kişilerin ülke sınırları dışında işledikleri savaş suçları dolayısıyla, ilgili kişileri yargılayabilecektir ${ }^{69}$. Son olarak UCM'nin zaman bakımından yargı yetkisinden bahsetmek gerekmektedir. Buna göre UCM, Statü'nün yürürlüğe girdiği 1 Temmuz 2002 tarihinden itibaren işlenen suçlar bakımından yetkili olacaktır ${ }^{70}$.

UCM'ye, ulusal mahkemeler karşısında tamamlayıcılık statüsü verilmiştir ${ }^{71}$. Bu durumda ulusal mahkemeler ile uluslararası mahkemeler arasında yarışan yetki sorunu karşımıza çıkmaktadır. Yarışan yetki halinde UCM Roma Statüsü ile düzenlenen bir suçun ulusal bir mahkemede yargılanması durumunda, UCM'nin yetkisizlik kararı vermesi gerekmektedir. Ulusal mahkemenin yargilama konusunda isteksiz olmas1 ya da yargılama yapamaması üzerine, bir uluslararası mahkeme olarak UCM'nin yarg1 yetkisinden bahsetmek mümkün olabilecektir ${ }^{72}$. Ayrıca Devletlerin uluslararası suçlar bakımından yargılama yetkisini kullanmadıkları zaman başka bir devletin bu yargı yetkisini kullanmasına

${ }^{67}$ ÇINAR, Fatih: Uluslarara Ceza Mahkemelerinin Gelişimi Işı̆̆ında Uluslararası Ceza Divanı (Uluslararası Ceza Divanı), Kazanc1, İstanbul 2004, s. 38; SCHABAS, An Introduction, ss. $78-79$.

${ }^{68}$ ÇINAR, Uluslaraarsı Ceza Divanı, s. 41; SMEULERS/GRUNFELD, International Crimes and Other Gross Human Rights Violations, s. 44.

${ }^{69}$ ÇINAR, Uluslararası Ceza Divanı, s. 39; RASTAN, Rod: "Jurisdiction", in STAHN, Catsyen (ed.), The Law and Practice of the International Criminal Court, Oxford University Press, UK 2015, ss.151 - 163.

${ }^{70}$ UCM Statüsü, XI. madde.

${ }^{71}$ UCM Statüsü, Giriş Bölümü.

${ }^{72}$ HALATÇI, Ülkü: "Uluslararası Ceza Mahkemesi'nin Yargı Yetkisini Kullanabilmesinin Önkoşulları”, Uluslararası Hukuk ve Politika, 2(3), 2005, s. 59; ÖNOK, Murat: Tarihi Perspektifiyle Uluslararası Ceza Divanı, Turhan Kitabevi, Ankara 2003, s. 139. 
izin vermesi ya da UCM'nin yargılamasına sevk etme hakları her zaman mevcuttur ${ }^{73}$.

Uluslararası suçlar bakımıdan maddi yargı yetkisi kapsamında savaş suçlarının UCM tarafından yargılanabilmesi için, UCM'nin yargı yetkisinin kabul edilmesi gerekmektedir. UCM'nin yarg1 yetkisini kullanabilmesinin önkoşulları, UCM Roma Statüsü 12. maddede sayılmıştır. Söz konusu madde esas olarak şu üç durumu düzenlemektedir: Öncelikle UCM'nin, Statüye taraf devletler ile ilgili olarak yargı yetkisini kullanabileceği suçlar, Statü’ye taraf olan hangi devletler için yargi yetkisini kullanabilemesinin kapsamı ve sinırı, Statü'ye taraf olmayan devletler için yargı yetkisinin durumu ${ }^{74}$.

UCM'nin maddi yarg1 yetkisinin yanında kişi bakımından yargı yetkisi uyarınca yargılanacak şahsın uyruğunda olduğu devletin ya da suçun işlendiği ülkenin devletinin Statü'ye taraf olması ya da Statü’ye taraf olmadan UCM'nin yarg1 yetkisini kabul ettiğini bildirmesi gerekmektedir $^{75}$. UCM Statüsü'nü kabul eden ve dolayısıyla UCM'nin yarg1 yetkisini kabul eden devlet Statü'de yer alan suçlarla ilgili bir dava getirebileceği gibi, Mahkeme savcısı da kendiliğinden harekete geçebilir ${ }^{76}$.

Son olarak konumuz bakımdan da önem arz eden husus, Statü'ye taraf olmayan devletler bakımından UCM'nin yargı yetkisidir. Söz konusu durumda, çatışmanın tarafı olan devlet Statü'ye taraf olmadan da tek taraflı beyanıyla, UCM'nin yargı yetkisini kabul edebilir. Hem Statü'ye taraf olmayıp hem de UCM'nin yargı yetkisini kabul etmemiş devletler bakımından ise, UCM'nin yargı yetkisinin doğmasının tek yolu, Birleşmiş Milletler Güvenlik Konseyi kararı ile ilgili devletteki durumun UCM'ye sevk edilmesidir ${ }^{77}$. Nitekim Güvenlik Konseyi'nin 31 Mart 2005 tarihli ve 1593 sayılı kararı ile Sudan'da işlenen suçlar UCM'ye sevk edilmiştir ${ }^{78}$. Devam eden yıllarda, Libya'daki iç yavaş sonucunda başgösteren ağır

${ }^{73}$ BAŞAK, Uluslararası Ceza Mahkemesi, $\quad$ s. CRYER/FRIMAN/ROBINSON/WILMSHURST, An Introduction, ss. 153- 162; El ZEIDY, Mohamed M.: The Principle of Complementarity in International Criminal Law Origin, Development and Practice, Martinus Nijjhof Publishers, Leiden 2010, ss. 157238.

74 HALATÇI, s. 60; ŞEN, Ersan: Uluslararası Ceza Mahkemesi, Seçkin Yayınları, İstanbul, 2009, s. $83-85$.

${ }^{75}$ UCM Roma Statüsü, XII. Madde.

${ }^{76}$ UCM Roma Statüsü, XIII. Madde.

${ }^{77}$ UCM Roma Statüsü, XVI. Madde.

${ }^{78}$ S/RES/1593, 2005, s. 1. 
insan hakları ihlalleri ile de ilgili olarak 26 Şubat tarihli ve 1970 sayılı Güvenlik Konseyi kararıyla, Libya'daki durum da, UCM'ye sevk edilmiştir $^{79}$. Son olarak Suriye'de yaşanan iç savaşla ilgili durum da UCM'ye sevk edilmek istenmiş, ancak Çin ve Rusya'nın vetosu nedeniyle sevk kararı alınamamıştır ${ }^{80}$.

Birleşmiş Milletler Güvenlik Konseyi'ne verilen işbu yetki Roma Konferansı sırasında tartışma konusu olmuş, bazı devletler Güvenlik Konseyi'nin UCM'yi harekete geçirme yetkisinin olmaması gerektiğini ileri sürmüştür. Söz konusu çekimserliğin temel sebebi, Birleşmiş Milletler Güvenlik Konseyi'nin yapısından kaynaklanan bir sorunsaldır. Böyle bir durumda, Güvenlik Konseyi’nin üyelerinin yaklaşımlarına göre, benzer nitelikteki durumlar karşısında farklı sonuçlar ortaya çıkmasının mümkün olabileceği ifade edilmiştit ${ }^{81}$.

\section{SONUÇ VE DEĞERLENDIRME}

Sonuç olarak uluslararası ve uluslararası olmayan silahlı çatışmalar bakımından, kültürel mallarına karşı yapılan saldırılar, ciddi insancıl hukuk ihlallerine vücut verecektir. Bu durumda, silahlı çatışmalarda devletin ve devlet ajanlarının kültürel malvarlığının korunmasına ilişkin yükümlülüklerle bağlı oldukları aşikârdır. Bu yükümlülüğün ihlali, savaş suçuna vücut verecek ve devlet adına hareket eden bireylerin uluslararası suçlar bakımından cezai sorumluluğu doğacaktır.

Uluslararası nitelikte olmayan çatışmalar bakımından, devlet dışı aktörlerin de, yukarıda saydığımız istisnalar dışında, insancıl hukukla bağlı olduğu artık kabul edilmektedir. Dolayısıyla, kültürel malvarlığına saldırı yasağı, devlet dışı aktörlerin ve devlet dışı aktörler adına faaliyette bulunan bireyler için de mevcuttur. Söz konusu aktörlerin kültürel malvarlığına vereceği zarar, uluslararası silahlı çatışmalarda olduğu gibi, ciddi insancıl hukuk ihlalleri olarak kabul edilip savaş suçuna vücut verecektir $^{82}$.

\footnotetext{
${ }^{79}$ S/RES/1970, 2011, s. 2

80 "Referral of Syria to International Criminal Court Fails as Negative Votes Prevent Security Council from Adopting Draft Resolution", 22 May 2014, http://www.un.org/press/en/2014/sc11407.doc.htm (Erişim Tarihi: 10.11.2017)

${ }^{81}$ HALATÇI, s. 75.

${ }^{82}$ IŞ่̇D'in Irak'taki faaliyetleri bakımından Birleşmiş Milletler Irak Yardım Misyonu ve Birleşmiş Milletler İnsan Hakları Yüksek Komiserliği'nin Aralık 2014 tarihinde yayınladığı raporda; IŞID'in Irak'ta kültürel malvarlığına gerçekleştirdiği saldırılara değinilerek, raporun sonuç kısmında işbu saldırıların savaş suçuna ve insanlığa karşı suça vücut verebileceği ifade edilmiştir. Bkz. Report of the office of the united nations
} 
high commissioner for human rights on the human rights situation in Iraq in the light of abuses committed by the so-called Islamic State in Iraq and the Levant and associated groups

(Report), (http://www.ohchr.org/EN/HRBodies/HRC/RegularSessions/Session30/Documents/A_H RC_30_66_ENG.docx (Erişim Tarihi: 10.11.2017), s. 12.

Raporun bireysel cezai sorumluluk başlıklı kısmında IŞiD'in Irak'ta dini açıdan etnik farkl1lıkları olan gruplara yönelik faaliyetleri, söz konusu grupların ibadet yerlerine saldırıları ve tarihi eserlerin maruz kaldığı saldırıların savaş suçu teşkil ettiği ifade edilmiştir. Söz konusu suçların yargılanması için Irak hükümetini Roma statüsüne taraf olmaya, Birleşmiş Milletler İnsan Hakları Konseyi'ni de Güvenlik Konseyi'ni Irak'ta işlenen uluslararası suçların kovuşturulması için karar almaya davet etmesini önermiştir. (Report, ss. 15 - 16)

Söz konusu rapor sonrasında farklı görüşlerin ileri sürülmesine sebep olmuştur. Fransa Dış İşleri Bakanı Laurent Fabius, meselenin Güvenlik Konseyi tarafindan UCM'ye sevk edilmesi gerektiğini ifade etmiştir. (NICHOLS, 2015) ABD Dış İşleri Konseyi'nde danışmanlık yapan John B. Beelinger de söz konusu raporla ilgili olarak, raporun pratik değerinin olmadığı, ortada davalı sıfatıyla yargılanacak kimse olmadığını ifade etmiş ve UCM'nin yapacağı soruşturmanın acizce yapılan uluslarüstü hukuki bir pratik teşkil edip etmeyeceğini sorgulamıştır. Bellinger sorduğu bu soruya olumsuz cevap vererek, IŞṠंD militanlarının işlediği suçların UCM kapsamına girdiği, militanların ulusal mahkemelerde yargılanmak yerine, UCM'de yargılanmasının daha mantıklı olduğunu ileri sürmüştür. (BELLINGER, John B.: Make ISIS' Leaders Face Justice, https://www.nytimes.com/ 2015/04/03/opinion/make-isis-leaders-face-justice.html?_r=0 (Erişim Tarihi: 10.11.2017).

Londra Üniversitesi Profosörü Kevin Jon Heller, Billinger'in yorumunu eleştirerek, Birleşmiş Milletler Güvenlik Konseyi başvurusunun gerekli olmadığını, UCM'nin ülkesel yetkisi yanında kişi bakımından yargı yetkisi de olduğunu ifade etmiştir. Nitekim IŞiD liderlerinden pek çoğunun UCM statüsü'ne taraf devlet vatandaşı olduğunu belirtilmiştir. Burada en çok adı geçen kişi Birleşik Krallık vatandaşı olan Jihadi John'dur. Bunun yanında Heller, yapılan başvuruda Suriye'de merkezi yönetimle savaşan diğer grupları yetki dışı bırakmasının mümkün olup olmayacağını sorgulamaktadır. İşbu grupların faaliyetlerinin yargılanmasının bu kez ABD, Fransa ve Birleşik Krallık tarafindan da istenilen bir durum olmayacağı belirtilmiştir. Heller, UCM'nin kaynaklarının zaten kısıtlı olduğunu belirterek ve IŞiD liderlerinin ABD, Birleşik Krallık, Japonya gibi devletler tarafindan yargılanabilecekken neden UCM'nin işbu devletler yerine ve bu devletler için çalışacağını sorgulamıştır. Dolayısıyla da UCM'nin, uluslararası suçları kovuşturmak bakımından en iyi çözüm olduğu varsayımından vazgeçmemiz gerektiğini, zaten UCM'nin yargılayacağı kişilerin de bir elin parmaklarını geçmeyeceği yorumunda bulunmuştur. Son olarak Heller, Darfur'da yaşandığı üzere, başka bir başarısız savunmaya ihtiyacımız olmadığını vurgulamıştır. (HELLER, Kevin John: John Bellinger's Op-Ed on ISIS and the ICC, http://opinio juris.org/2015/04/02/john-bellingers-curious-op-ed-on-isis-and-the-icc/, (Erişim Tarihi: 10.11.2017)

İşbu meselede tartışmalara sebep olan husus Suriye ve Irak'ta yaşananların direkt UCM'ye sevk edilmesi halinde, UCM'nin yarg1 yetkisinin bütün taraflar bakımından doğacak olmasıdır. İlgili durumda Rusya ve Çin'in veto yetkisini kullanması söz konusu olabilecektir. Karşı karşıya olduğumuz bu siyasi meselenin çözümü bakımından 
Buna göre; evrensel suçlarda mülkilik ilkesi öncelikli olduğu için savaş suçlarına vücut veren kültürel malvarlığına saldırının sorumlularının, suçun işlendiği yer mahkemeleri tarafından yargılanması mümkündür. Ancak suçun işlendiği devletler, geçirdikleri ağır çatıșma ortamı yüzünden, çoğu zaman sorumluları gerektiği gibi yargılamak mümkün olmamaktadır.

Hal böyle olunca, uluslararası suçlarda yarg1 yetkisi bakımından ikinci olasılık devreye girmektedir: kişi bakımından yargı yetkisi. Buna göre, özellikle devlet-dışı aktörler bakımından, savaş suçu işleyen kişiler suçun vuku bulduğu devletten başka bir devletin vatandaşı ise, o devlet de kişi bakımından yargı yetkisi dolayısıyla, savaş suçu işleyen şahsı yargilayabilir.

Ulusal yarg1 yetkileri yanında, UCM'nin yargı yetkisi ancak belli şartlarda mümkün olabilecektir. Savaş suçunun vuku bulduğu devletin UCM Roma Statüsü'ne taraf olması halinde, yer bakımından yargı yetkisi dolayısıyla, UCM'nin ilgili suç bakımından suçu işleyen şahıslar üzerinde yarg1 yetkisi olabilecektir.

uluslararası hukuk profösürü William Schabas'ın önerisi bir hayli ilginçtir. Schabas, UCM Roma Statüsü'ne taraf olmayan bir devlette faaliyet gösteren bir grubun faaliyetlerinin UCM'ye sevk edilmesinin imkansız olduğunu söyleyen bir kural olmadığını dile getirmiştir. Yani Schabas, salt bir grup olarak tek başına IŞiD’in faaliyetlerinin UCM önüne getirilebileceğini, IŞiD’e ilişkin yapılacak başvurunun meşru olduğunun kabul edilmesi halinde, bunun savcı ve hakimler için bir ilk olacağını belirtmiştir. UCM'nin devreye girmesi halinde -ki Schabas bu şekilde girebileceği görüşündedir- Güvenlik Konseyi başvurusunu, yorum yoluyla Suriye ve Irak'taki tüm gruplar bakımından genişletmesinin de mümkün olduğunu ifade etmiştir. (NICHOLS, Michelle: France Presses at U.N. for Islamic State to Face World Court, http://m.thestar.com.my/story.aspx?hl

$=$ France + presses + at $+\mathrm{UN}+$ for + Islamic + State + to + face + world + court $\&$ sec $=$ ews $\& i d=\% 7 \mathrm{~B} 9$ B37534F-CA36-4759-BDBA-AADE5789CAFE\%7D , (Erişim Tarihi: 10.11.2017).

UCM savcısı Fatou Bensouda 8 Nisan 2015 tarihinde yaptığı açıklamada, IŞiD'in gerek Irak'ta gerek Suriye'de gerçekleştirdiği faaliyetler dolayısıyla, 2014 yazından bu yana UCM savcılığına pek çok suç duyurusu ulaştı̆̆ını ve şikayet edilen eylemler arasında kültürel malvarlığının kasten yok edilmesinin de dahil olduğunu ifade etmiştir. Savcı, IŞiD'in bölgede gerçekleştirdiği faaliyetlerin pek tabi uluslararası topluma karşı ciddi bir suç teşkil ettiğini kabul etmekle birlikte, hem Irak'ın hem de Suriye'nin UCM Roma Statüsü'ne taraf olmaması sebebiyle, UCM'nin ilgili suçlar bakımından yarg1 yetkisi olmadığını açıkça beyan etmiştir. (Statement of the Prosecutor of the International Criminal Court, Fatou Bensouda, on the alleged crimes committed by ISIS (2015), https://www.icc-cpi.int/Pages/item.aspx?name=otp-stat-08-04-2015-1 (Erişim Tarihi: 10.11.2017). 
UCM'nin yarg1 yetkisine ilişkin ikinci olasılık da, özellikle devletdışı örgütlerde faaliyet gösteren şahıslar açısından, vatandaşı oldukları devletin UCM Statüsü'ne taraf olması halinde, sorumlu şahısların UCM'de yargilanmasidır.

Son olarak, Birleşmiş Milletler Güvenlik Konseyi'nin UCM'yi yetkilendirmesi de söz konusu olabilir. İşbu durumda gerek uluslararası çatışmalarda gerek uluslararası olmayan çatışmalarda, savaş suçu işleyen bireylerin Güvenlik Konseyi'nin yetkilendirmesiyle, UCM'de yargılanması mümkün olabilecektir. Ancak Güvenlik Konseyi daimî üyelerinin veto yetkisi dolayısıyla, UCM'nin yetkilendirilmesi devletlerin siyasi tercihleriyle bağlı olacaktır.

İnsancıl hukuk kuralları, çatışan tarafların hak ve yükümlülüklerini öngörmüş olsa da söz konusu ihlaller halinde bireylerin cezai sorumluluğunun öngörüldüğü uluslararası ceza hukukunun yaptırımlarına başvurmak, kültürel malvarlığının korunması rejiminin en etkili araçlarından biridir. Ancak önemli olan, kültürel malvarlığının zarar görmeden korunmasını sağlamak olmalıdır. Söz konusu rejim pasif bir koruma sağlamakta, koruma yükümlülügüne ek olarak zarar görme halini de cezalandırmaktadır. Halbuki zarar gördükten sonra, kültürel malvarlığının korunmasına ilişkin yükümlülük getirmenin ve yükümlülüğün ihlali halinde cezai yaptırım öngörülmesi, malvarlığının tahribi ve yok olması karşısında önemini yitirmektedir. İşbu durumda kültürel malvarlığının zarar görmesi ve yok olmasını engelleyecek aktif koruma araçlarının geliştirilmesi gereği aşikardır. 


\section{Kaynakça}

\section{Kitaplar ve Kitap Bölümleri}

AKSAR, Yusuf: Implementing International Humanitarian Law from the Ad Hoc Tribunals to a Permanent International Criminal Court Routhledge, London 2004.

BANTEKAS, Illias/NASH, Susan: International Criminal Court, Routhledge, UK 2007, s. 113.

BAŞAK, Cengiz: Uluslararası Ceza Mahkemesi ve Uluslararası Suçlar (Uluslararası Ceza Mahkemesi), Turhan Kitabevi, Ankara 2003.

BATUR YAMANER, Melike/ÖKTEM, Emre, KURTDARCAN, Bleda R./UZUN, Mehmet C.: 12 Ağustos 1949 Tarihli Cenevre Sözleşmeleri ve Ek Protokolleri (Cenevre Sözleşmeleri), Galatasaray Üniversitesi Hukuk Fakültesi Yayınları, No: 42, İstanbul.

BIANCHI, Andrea- NAQVI, Yasmin: International Humanitarian Law and Terrorism, Hart Publishing, USA 2011.

CASSESE, Antonio: International Criminal Law, Oxford University Press, UK 2003.

CRYER, Robert/ FRIMAN, Hakan/ROBINSON, Darry/WILMSHURST, Elizabeth: An Introduction to International Criminal Law and Procedure (An Introduction), Cambridge University Press, UK 2014.

ÇINAR, Fatih: $\quad$ Uluslarara Ceza Mahkemelerinin Gelişimi Işı̆̆ında Uluslararası Ceza Divanı, Kazanc1, 2004.

DARCY, Shane: Judges, Law and War: The Judicial Development of International Humanitarian Law (Judges, Law and War), Cambridge University Press, UK 2014.

El ZEIDY, Mohamed M.: The Principle of Complementarity in International Criminal Law Origin, Development and Practice, Martinus Nijjhof Publishers, Leiden 2010.

HENCKAERTS, Jean-Marie: "New Rules for the Protection of Cultural Property in Armed Conflict: The Significance of the Second Protocol to the 1954 Hague Convention for the Protection of Cultural Property in the Event of Armed Conflict" in Protection of Cultural Property in the Event of Armed Conflict, International Committee of the Red Cross, Geneva 2002.

HLADIK, Jan: "The 1954 Hague Convention for the Protection of Cultural Property in the event of Armed Conflict: Some Observations on the Implementation at the National Level" in Protection of Cultural Property in the Event of Armed Conflict, International Committee of the Red Cross, Geneva 2002.

O'KEEFE, Roger: The Protection of Cultural Property in Armed Conflict, Cambridge University Press, UK 2006.

ÖNOK, Murat: Tarihi Perspektifiyle Uluslararası Ceza Divanı, Turhan Kitabevi, Ankara 2003.

ÖZEL, Sibel: Uluslararası Alanda Kültürel Malvarlı̆̆ının Korunması (Kültürel Malvarlığının Korunması), Alkım Yayınları, İstanbul 1998. 
PARTSCH, Karl Josef: "Protection of Cultural Property", in Fleck, Dieter (ed.), The Handbook of Humanitarian Law in Armed Conflict, Oxford University Press, NewYork 2004.

RASTAN, Rod: "Jurisdiction", in STAHN, Catsyen (ed.), The Law and Practice of the International Criminal Court, Oxford University Press, UK 2015.

ROWE, Peter: "War Crimes", in McGOLDRICK, Dominic/ROWE, Peter/DONNELLY, Eric (ed.), The Permanent International Criminal Court: Legal and Policy Issues, Hart Publishing, USA 2004.

SCHABAS, William: An Introduction to the International Criminal Court, Second Edition, Cambridge University Press, UK 2004.

SCHEFFER, David: "The International Criminal Court" in SCHABAS, William/BERNAZ, Nadia (ed.), Routhledge Handbook of International Criminal Law, Routhledge, London 2010.

SCOTT, James Brown (ed.): The Hague Convention and Declarations of 1899 and 1907, https://archive.org/stream/

hagueconventions00inteuoft\#page/n5/mode/2up, (Erişim Tarihi: 10.12.2017), 1915 .

SMEULERS, Alette/GRUNFELD, Fred: International Crimes and Other Gross Human Rights Violations a Multi and Interdisciplinary Textbook, Martinus Nijhoff Publishers, Leiden 2011.

TEZCAN, Durmuş/ERDEM, Mustafa Ruhan/ÖNOK, Rifat Murat: Uluslararası Ceza Hukuku Seçkin Yayınları, Ankara 2014.

TOMAN, Jiri: The Protection of Cultural Property in the Event of Armed Conflict, UNESCO Publishing, Paris 1996.

TÜTÜNCÜ, Ayşenur: İnsancıl Hukuka Giriş, Beta Yayınları, İstanbul 2006.

\section{Makaleler}

AYDIN, Devrim: "Uluslararası Ceza Hukukunun Gelişimi”, Ankara Üniversitesi Hukuk Fakültesi Dergisi, 52(4), 2002, 131 - 167.

BELLINGER, John B.: Make ISIS' Leaders Face Justice, https://www.nytimes.com/ 2015/04/03/opinion/make-isis-leaders-face-justice.html?_r=0 (Erişim Tarihi: 10.11.2017).

BHAT, P. Ishwara: "Protection of Cultural Property Under International Humanitarian Law: Some Emerging Trends", ISIL Yearbook of International Humanitarian and Refugee Law, No: 4, 2001, 47 - 71.

GÜNEYSU, Gökhan: “Askeri Gereklilik İlkesi ve Uluslararası İnsancıl Hukuk”, Ankara Barosu Dergisi, 4, 2012, 91 - 108.

HALATÇı, Ülkü: “Uluslararası Ceza Mahkemesi’nin Yargı Yetkisini Kullanabilmesinin Önkoşulları", Uluslararası Hukuk ve Politika, 2(3), 2005, 57 - 76.

HELLER, Kevin John: John Bellinger's Op-Ed on ISIS and the ICC, http://opiniojuris.org/2015/04/02/john-bellingers-curious-op-ed-onisis-and-the-icc/, (Erişim Tarihi: 10.11.2017)

NICHOLS, Michelle: France Presses at U.N. for Islamic State to Face World Court, http://m.thestar.com.my/story.aspx?hl=France+presses+at+UN+for+Isl amic+State+to+face+world+court \&sec=ews \&id $=\% 7 \mathrm{~B} 9 \mathrm{~B} 37534 \mathrm{~F}-$

CA36-4759-BDBA-AADE5789CAFE\%7D , (Erişim Tarihi: 10.11.2017).

POUST, Jordan: "Dr. Francis Lieber and Lieber Code", Proceedings of the Annual Meeting (American Society of International Law), 95, 2001, $112-115$. 
TECHERA, Erika: "Protection of Cultural Heritage in Times of Armed Conflict: The International Legal Framework Revisited" (Protection of Cultural Heritage), Macquarie J. Int'l\&Comp. Envtl.L, 4(1), 2007, 1 - 20.

\section{Belgeler}

Records of the General Conference, (1993), s. 40, http://unesdoc.unesco.org/images/0009/ 000956/095621E.pdf (Erişim Tarihi: 10.11.2017)

Records of the general conference, 1991, s. 57, http://unesdoc.unesco.org/images/0009/ 000904/090448E.pdf, (Erişim Tarihi: 10.11.2017)

Report of the office of the united nations high commissioner for human rights on the human rights situation in Iraq in the light of abuses committed by the so-called Islamic State in Iraq and the Levant and associated groups, (http://www.ohchr.org/EN/HRBodies/HRC/RegularSessions/Session30 /Documents/A_HRC_30_66_ENG.docx (Erişim Tarihi: 10.11.2017), s. 12.

S/RES/1593, 2005, s. 1.

S/RES/1970, 2011, s. 2

Statement of the Prosecutor of the International Criminal Court, Fatou Bensouda, on the alleged crimes committed by ISIS (2015), https://www.icccpi.int/Pages/item.aspx?name=otp-stat-08-04-2015-1 (Erişim Tarihi: 10.11.2017)

T.C. Resmi Gazete, 12145, 8 Kasim 1965.

\section{Linkler}

"ISIS destroy Palmyra's Roman amphitheatre after "beheading 4 and shooting 8 dead in ancient city",, http://www.mirror.co.uk/news/world-news/isis-destroypalmyras-roman-amphitheatre-9657148, (Erişim Tarihi: 20.12.2016)

"Referral of Syria to International Criminal Court Fails as Negative Votes Prevent Security Council from Adopting Draft Resolution", 22 May 2014, http://www.un.org/press/en/2014/sc11407.doc.htm (Erişim Tarihi: 10.11.2017)

"Syria, Destruction of Cultural Heritage", https://casebook.icrc.org/case-study/syriadestruction-cultural-heritage (Erişim Tarihi: 20.12.2017)

Destruction of Cultural Heritage in the Middle East by ISIS, http://www.gecmun.com/uploads/2/3/7/0/237 02810/ gecmun_iii_unesco.pdf, (Erişim Tarihi: 20.12.2017)

https://www.haberler.com/isid-in-musul-muzesi-ne-saldirisi-7015091-haberi/_ (Erişim Tarihi: 10.12.2017).

Practical Advice for Protection of Cultural Property by ICRC, 2002, https://www.icrc.org/en/document/ practical-advice-protectioncultural-property-event-armed-conflict-guidelines, (Erişim Tarihi:

\section{Kararlar} 15.12. 2017)

Prosecutor v Haradinaj, Dava No. IT-04-84-84-T, (Dava Dairesi), 3 Nisan 2008.

Procecutor v. Dario Kordic and Mario Cerkez Judgement, IT-95-14/2-T, 26 February 2001.

Prosecutor v. Boskoski, Dava No. IT-04-82, (Dava Dairesi), 10 Ağustos 2008.

Prosecutor v. Dusko Tadic (a/k/a Dule), No IT-94-1-AR-72, 2 Ekim 1995. 
